See discussions, stats, and author profiles for this publication at: https://www.researchgate.net/publication/333715764

\title{
Asynchronous variation in the Quaternary East Asian winter monsoon associated with the tropical Pacific ENSO-like system
}

Article in Geophysical Research Letters · June 2019

DOI: 10.1029/2019GL083033

CITATIONS

0

7 authors, including:

Debo Zhao

Chinese Academy of Sciences

18 PUBLICATIONS 108 CITATIONS

SEE PROFILE

Zhaoyang Song

GEOMAR Helmholtz Centre for Ocean Research Kiel

8 PUBLICATIONS 19 CITATIONS

SEE PROFILE
READS

161

Shiming Wan

Chinese Academy of Sciences

120 PUBLICATIONS 1,639 CITATIONS

SEE PROFILE

Xun Gong

Alfred Wegener Institute Helmholtz Centre for Polar and Marine Research

22 PUBLICATIONS 183 CITATIONS

SEE PROFILE

Some of the authors of this publication are also working on these related projects:

Project Interactions of Indian Monsoon, Ocean circulation and Weathering in South Asia View project

Project Testing the geologically testable hypothesis on subduction initiation View project 


\section{Geophysical Research Letters}

\section{RESEARCH LETTER \\ 10.1029/2019GL083033 \\ Key Points: \\ - Clay minerals in northern Okinawa Trough were derived from Yellow River and Kyushu \\ - Reversed EAWM evolution in the northern and southern East Asian marginal sea was revealed \\ - ENSO-like processes cause spatial discrepancy of Quaternary EAWM evolution}

Supporting Information:

- Supporting Information S1

Correspondence to:

S. Wan,

wanshiming@ms.qdio.ac.cn

Citation:

Zhao, D., Wan, S., Song, Z., Gong, X., Zhai, L., Shi, X., \& Li, A. (2019). Asynchronous variation in the Quaternary East Asian winter monsoon associated with the tropical Pacific ENSO-like system. Geophysical Research Letters, 46. https://doi.org/ 10.1029/2019GL083033

Received 27 MAR 2019 Accepted 5 JUN 2019

Accepted article online 11 JUN 2019

c)2019. American Geophysical Union. All Rights Reserved.

\section{Asynchronous Variation in the Quaternary East Asian Winter Monsoon Associated With the Tropical Pacific ENSO-Like System}

\author{
Debo Zhao' ${ }^{1}$, Shiming Wan ${ }^{1,2,3}$ (D), Zhaoyang Song ${ }^{4}\left(\mathbb{D}\right.$, Xun Gong ${ }^{5}$ (D) Lina Zhai ${ }^{1}$, \\ Xuefa $\mathrm{Shi}^{2,6}$ (ID), and Anchun $\mathrm{Li}^{1}$ (iD) \\ ${ }^{1}$ Key Laboratory of Marine Geology and Environment, Institute of Oceanology, Chinese Academy of Sciences, Qingdao, \\ China, ${ }^{2}$ Laboratory for Marine Geology, Qingdao National Laboratory for Marine Science and Technology, Qingdao, \\ China, ${ }^{3}$ CAS Center for Excellence in Quaternary Science and Global Change, Xi'an, China, ${ }^{4}$ GEOMAR Helmholtz Centre \\ for Ocean Research Kiel, Kiel, Germany, ${ }^{5}$ Alfred Wegener Institute, Helmholtz Centre for Polar and Marine Research, \\ Bremerhaven, Germany, ${ }^{6}$ Key Laboratory of Marine Sedimentology and Environmental Geology, First Institute of \\ Oceanography, Ministry of Natural Resources, Qingdao, China
}

Abstract Quaternary East Asian winter monsoon (EAWM) evolution has long been attributed to high-latitude Northern Hemisphere climate change. However, it cannot explain the distinct relationships of the EAWM in the northern and southern East Asian marginal sea in paleoclimatic records. Here we present an EAWM record of the northern East China Sea over the past $300 \mathrm{ka}$ and a transient climate simulation with the Kiel Climate Model through the Holocene. Both proxy record and simulation suggest anticorrelated long-term EAWM evolution between the northern East China Sea and the South China Sea. We suggest that this spatial discrepancy of EAWM can be interpreted as El Niño-Southern Oscillation (ENSO)-like controlling, which generates cyclonic/anticyclonic wind anomalies in the northern/southern East Asian marginal sea. This research explains much of the controversy in nonorbital scale variability of Quaternary EAWM records in the East Asian marginal sea and supports a potent role of tropical forcing in East Asian winter climate change.

Plain Language Summary The modern East Asian winter monsoon (EAWM) is influenced by the combined effects of both the high-latitude Northern Hemisphere (e.g., Siberian High) and the low-latitude Western Pacific (e.g., El Niño-Southern Oscillation) and plays a major role in regulating atmospheric energy of East Asia and even the Northern Hemisphere. Its anomalies may cause extremely cold/warm winter weather or climate events, which result in profound societal and economic influences on the densely populated region of East Asia. Especially, some studies found the EAWM displays spatial discrepancies in northern and southern East Asia and can result in a colder/warmer north corresponding to a warmer/colder south. Our study shows anticorrelations of EAWM evolution between the northern East Asian marginal sea and the South China Sea since the late Quaternary. We suggest that such spatial discrepancies of EAWM evolution were controlled by El Niño-Southern Oscillation-like processes in the tropical Pacific. During El Niño-like conditions, the anomalous northwesterlies in the northern East Asian marginal sea led to a strengthened EAWM in this region. In contrast, anomalous southwesterlies in the South China Sea favored the occurrence of a weakened EAWM. The opposite situation occurred under La Niña-like conditions.

\section{Introduction}

The East Asian winter monsoon (EAWM), characterized by cold and dry northwesterlies over the eastern marginal sea of the Asian continent and northeasterlies over the South China Sea, is a specific feature of the East Asian monsoon and could be influenced by the combined effect from both the high-latitude Northern Hemisphere and the low-latitude Western Pacific (Figure 1; Liu \& Ding, 1998; Wang et al., 2000). The EAWM anomalies may cause extremely cold/warm winter weather or climate events, which have profound societal and economic influences on this densely populated region of East Asia (Gao et al., 2008; Wang et al., 2011).

Over the past several decades, the EAWM intensity during the Quaternary has been reconstructed mainly on the basis of loess (Hao et al., 2012; Liu \& Ding, 1998; Sun et al., 2006) and marine sediment records (Li et al., 


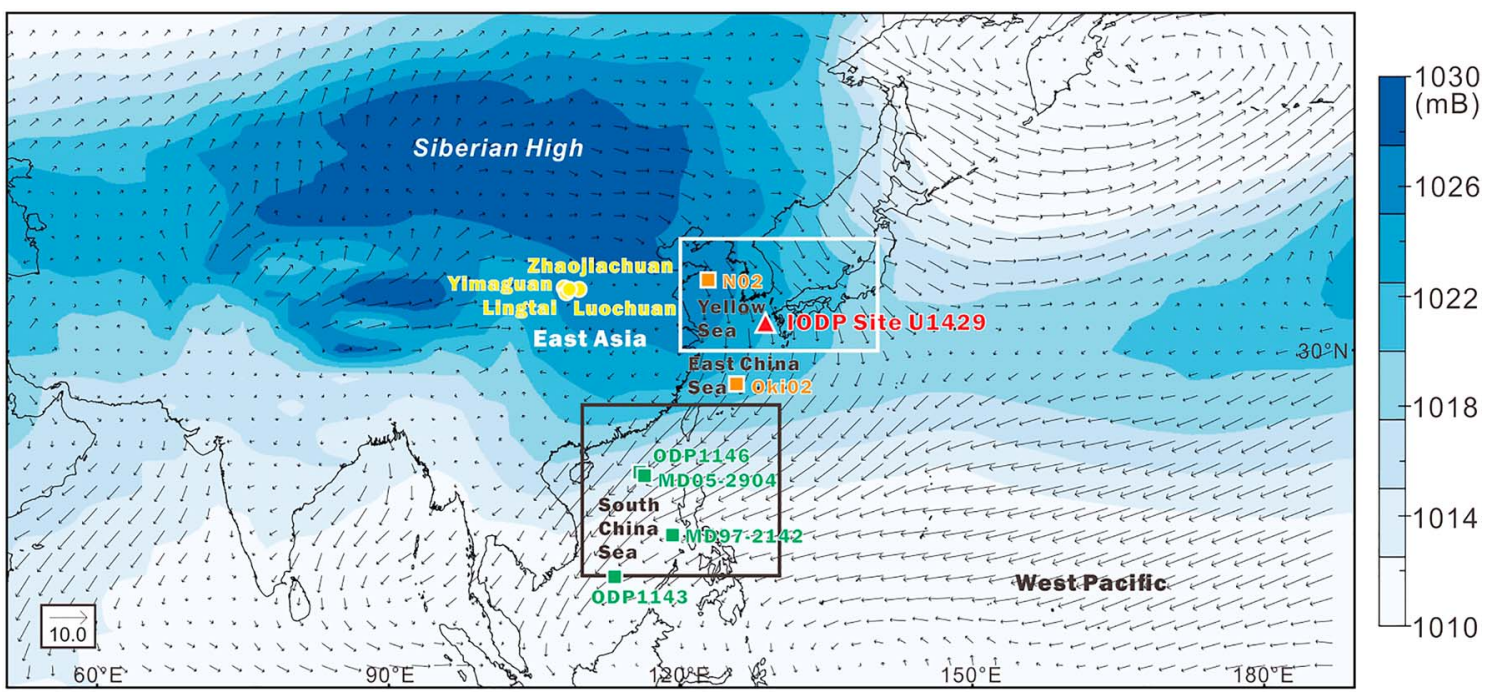

Figure 1. Locations of IODP Site U1429 and referenced sites with surface circulation over Asia and the western Pacific in winter. Data on monthly surface vector winds (black arrows) and sea level pressure in January 2016 are from NCEP/NCAR Reanalysis 1. White and black boxes indicate the Kiel Climate Model domains of the northern East Asian marginal sea (30-40 $\left.{ }^{\circ} \mathrm{N}, 120-140^{\circ} \mathrm{E}\right)$ and the South China Sea $\left(10-25^{\circ} \mathrm{N}, 110-130^{\circ} \mathrm{E}\right)$, respectively, for calculating the averaged 10-m meridional wind vector of the EAWM. The averaged wind is multiplied by -1 to derive a positive East Asian winter monsoon index. IODIntegrated Ocean Drilling Program.

2017; Yamamoto et al., 2013). These studies have commonly suggested an intensified glacial EAWM compared to interglacial periods. However, EAWM evolution remains under debate for its long-term trend in the late Quaternary (Huang, 2015) and the variations at multimillennial scales (Hao et al., 2017; Steinke et al., 2011). In particular, paleoclimate proxies have suggested inconsistent EAWM patterns between the northern and southern East Asian regions since the middle Pleistocene (Hao et al., 2017; Huang, 2015; Steinke et al., 2011), suggesting that the EAWM complexity involves regional heterogeneities. Studies have linked solar insolation and the resultant variations in atmospheric circulation over the East Asian continent and Pacific to the EAWM system (Kutzbach, 1981; Wen et al., 2016). Moreover, Northern Hemisphere ice volume may enhance the Siberian High and EAWM on orbital scales by regulating the ice and snow accumulation in northern high latitudes (Hao et al., 2012). Furthermore, Atlantic meridional overturning circulation has also been identified as a driver of abrupt changes in the EAWM on the millennial scale (Sun et al., 2011). Nevertheless, both the orbital and northern high-latitude forcings cannot fully explain the regional difference in nonorbital-scale variability in the Quaternary EAWM.

El Niño-Southern Oscillation (ENSO) can physically govern the convective activities over the western equatorial Pacific, leading to different wind anomalies occurring in the lower troposphere of the western Pacific and northeastern East Asia and consequently causing distinct EAWM intensities on the decadal scale (Sun \& Yang, 2005). Simulations based on the observation data have shown that the El Niño mode can result in an enhanced EAWM in northern East Asia but a subdued EAWM in southern East Asia, leading to a colder northern but warmer southern East Asia (Sun \& Yang, 2005). In contrast, scenarios with extremely frigid temperatures in southern China induced by strengthened EAWM often occur in a strong La Niña mode (e.g., 2008 Chinese winter storms; Gao et al., 2008). Overall, the ENSO processes have significant impacts on the EAWM in the modern climate, while its role in changing the EAWM long-term variations during the late Quaternary remains unclear.

The climate records in the northern East Asian marginal sea could be ideal candidates for the reconstruction of the EAWM evolution. Satellite observation and paleorecord studies have all demonstrated that the transport of sediments from the East Asian continent to the Yellow Sea and Okinawa Trough was mainly forced by the EAWM (Figure S1 in the supporting information; Hao et al., 2017; Pang et al., 2016; Yuan et al., 2008; Zheng et al., 2014). The modern suspended sediment concentration in the Yellow Sea suggests strong seasonal variation (Figure S2), with differences of $40 \mathrm{mg} / \mathrm{L}$ in the old Yellow River mouth and $10 \mathrm{mg} / \mathrm{L}$ in the 
southeastern Yellow Sea between winter and summer (Pang et al., 2010). In addition, suspended sediment concentration is highly correlated with winter monsoon speed over the Yellow Sea on seasonal and interannual scales (Figure S2). Here we present a high-resolution sediment record using clay mineral and terrigenous material flux at the Integrated Ocean Drilling Program (IODP) Site U1429 in the northern Okinawa Trough in the East China Sea to create a continuous reconstruction of EAWM evolution in the northern region of the East Asian marginal sea over the last $300 \mathrm{ka}$ (Figure 1). In addition, EAWM intensities in the northern East Asian marginal sea and South China Sea through the Holocene have also been investigated by a long-term transient model simulation. In our results, variations in the EAWM in the northern East Asian marginal sea are anticorrelated with those over the South China Sea not only on a long-term trend over the past $300 \mathrm{ka}$ but also on multimillennial scales during the Holocene. Moreover, high coherencies between EAWM in these two areas and the tropical Pacific sea surface temperature (SST) gradient suggest that the ENSO-like process has been a critical factor in regulating the distinct EAWM evolution in the northern and southern East Asia marginal sea during the late Quaternary.

\section{Materials and Methods}

IODP Site U1429 $\left(31^{\circ} 37.04^{\prime} \mathrm{N}, 128^{\circ} 59.85^{\prime} \mathrm{E}\right)$ is located in the northeastern East China Sea, on the western continental slope of the northern Okinawa Trough at a water depth of $732 \mathrm{~m}$ (Figure 1). The lithology of the recovered section from IODP Site U1429 is mainly calcareous nannofossil ooze and calcareous nannofossil-rich clay (Tada et al., 2014). The age model for IODP Site U1429 was developed by correlating the $\delta^{18} \mathrm{O}$ record obtained from benthic foraminifera with the LR04 $\delta^{18} \mathrm{O}$ stack combined with tephrostratigraphy (Sagawa et al., 2018). The linear sedimentation rates varied between 24.0 and $160.8 \mathrm{~cm} / \mathrm{ka}$, with an average value of $53.5 \mathrm{~cm} / \mathrm{ka}$ (Figure S3). For this study, a total of 1,245 samples were taken at 10-cm intervals from 21 to $151.1 \mathrm{~m}$ at IODP Site U1429 to perform the mineralogical composition analysis of the clay fraction using X-ray diffraction and tracing the clay-sized sediment provenance. To determine the sediment flux, we also calculated the relative sediment supply and terrigenous mass accumulation rate. Here we combined previous clay results (from the upper $20.99 \mathrm{~m}$ of IODP Site U1429; Zhao et al., 2017) and new clay mineralogical data to reconstruct the EAWM intensity during the last $300 \mathrm{ka}$ with the clay mineral ratio illite/smectite and the Yellow River terrigenous mass accumulation rate. We also conducted an orbital accelerated transient simulation of the Holocene, performed with the Kiel Climate Model (KCM) to investigate the EAWM evolution during the Holocene in the northern East Asian marginal sea $\left(30-40{ }^{\circ} \mathrm{N}, 120-140\right.$ ${ }^{\circ} \mathrm{E}$ ) and South China Sea (10-25 ${ }^{\circ} \mathrm{N}, 110-130^{\circ} \mathrm{E}$; Figure 1). In addition, we conducted a cross-spectral analysis to examine periodicities and further assess the intrinsic mechanism of EAWM change in the frequency domain. More detailed information on the analytical methods is provided in the Text S1 and Figures S3-S7 in the supporting information (Beny et al., 2018; Diekmann et al., 2008; Fan et al., 2001; Grant et al., 2014; Howell et al., 2006; Khon et al., 2018; Kim, 1979; C. Li et al., 2012; Li et al., 2018; Licht et al., 2016; Milliman \& Farnsworth, 2013; Ohtsubo et al., 1995; Pang et al., 2010; Park et al., 2009; Park \& Khim, 1990; Rea \& Janecek, 1981; Ren \& Shi, 1986; Sagawa et al., 2018; Schneider et al., 2010; Song et al., 2016; Sun et al., 2015; Wan et al., 2007; Wan et al., 2012; Yang et al., 2003; Yuan et al., 2008; Zhao et al., 2017; Zheng et al., 2016; Zheng et al., 2014).

\section{Results}

The reconstructed EAWM suggests weak glacial-interglacial cycles, with relatively increased winter winds during MIS 8, 6, early 4, early 2 and 1 and decreased winter winds during MIS 7 and 3, except for abrupt increases at approximately 220-210 ka and 50-40 ka. Additionally, frequent fluctuations were observed during MIS 5 (Figure 2d). Such patterns resemble the EAWM reconstruction based on the records from the Loess Plateau to some extent, at the scale of glacial-interglacial cycles (Figures 2c and 2d; Hao et al., 2012; Sun et al., 2006).

On the long-term trend, the EAWM in the northern East Asian marginal sea suggests intensification from $\sim 300$ to $\sim 160 \mathrm{ka}$ and then gradually weakened from $\sim 160 \mathrm{ka}$ to the present (Figure $2 \mathrm{~d}$ ). The historical long-term evolution of EAWM since the last $300 \mathrm{ka}$ in the South China Sea region was reconstructed based on the records of the south-north SST gradient (Huang, 2015; Figure 2e). The south-north SST gradient has long been adopted as an EAWM proxy in the South China Sea (Huang, 2015; L. Li et al., 2012; Tian et al., 


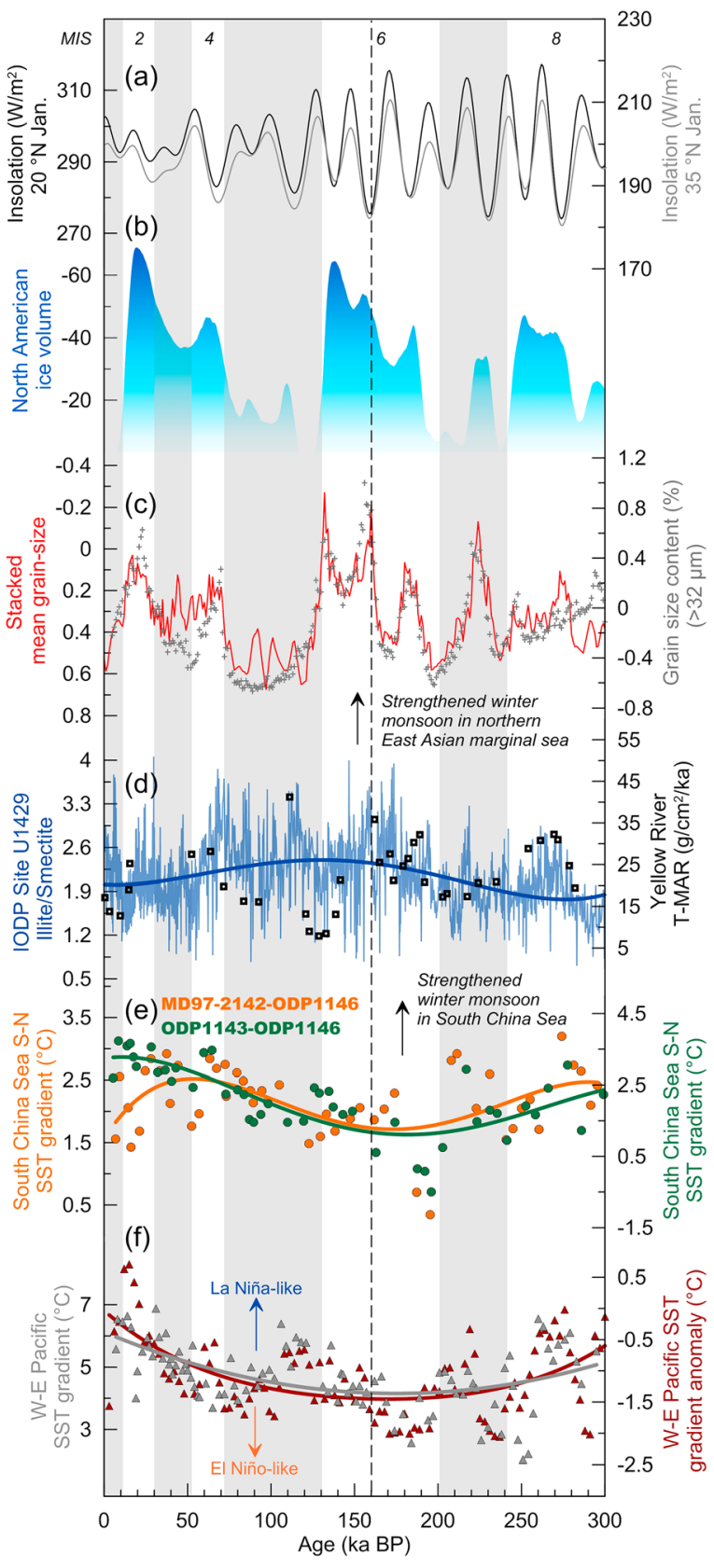

Figure 2. Comparison of proxy records of EAWM from northern East Asian marginal sea, Loess Plateau and South China Sea with global paleoenvironmental records during the last $300 \mathrm{ka}$. (a) Northern Hemisphere insolation at $20^{\circ} \mathrm{N}$ and $35^{\circ} \mathrm{N}$ in January; (b) North American ice volume (Bintanja et al., 2005);

(c) EAWM records including stacked mean grain size (Sun et al., 2006) and grain size content (Hao et al., 2012) on the Loess Plateau; (d) U1429 clay mineral ratio and Yellow River terrigenous mass accumulation rate; (e) EAWM records in the South China Sea based on south-north SST gradients, orange line:

MD97-2142-ODP1146 and green line: ODP1143-ODP1146 (Huang, 2015); (f) El Niño-Southern Oscillation-like proxies based on west-east Pacific SST gradient (MD97-2140-ODP846; de Garidel-Thoron et al., 2005) and west-east Pacific zonal SST gradient anomaly (Jia et al., 2018). Thick lines are polynomial fits shown to highlight general long-term trends in the original data sets. The EAWM records are subdivided into two time intervals by the vertical black dotted line. EAWM = East Asian winter monsoon; IODIntegrated Ocean Drilling Program; SST $=$ sea surface temperature.
2010). For the long-term evolution, the EAWM records in the South China Sea suggest an overall inverse trend compared to our records in the northern East China Sea, indicating a weakened EAWM from $\sim 300$ to $\sim 160 \mathrm{ka}$ and a strengthened winter monsoon from $\sim 160 \mathrm{ka}$ to the present in the South China Sea (Figures 2d and 2e).

On the multimillennial scale, multiple proxies associated with the EAWM in the northern region of the East Asian marginal sea since the last $8.5 \mathrm{ka}$ in the Holocene are displayed in Figure 3b. Long-term intensified EAWM since the last $8.5 \mathrm{ka}$ is observed based on the illite/smectite ratio. These results suggest a high coherency with other EAWM records in the middle Okinawa Trough and central Yellow Sea surrounding this area (Figure 3b; Hao et al., 2017; Zheng et al., 2014). The Holocene EAWM in the South China Sea was reconstructed based on the temperature gradient between surface and thermocline waters by Steinke et al. (2011), as well as the east-west SST gradient by Huang et al. (2011) in the South China Sea. Contrasting variations in the EAWM between the northern East Asian marginal sea and the South China Sea were observed. The long-term intensified EAWM in the northern East Asian marginal sea was synchronous with a weakened EAWM in the South China Sea since the last $8.5 \mathrm{ka}$ in the Holocene (Figures $3 \mathrm{~b}$ and $3 \mathrm{~d}$ ).

In addition, the simulated EAWM suggests a long-term intensified EAWM from early to late Holocene in the northern East Asian marginal sea and weakened EAWM in the South China Sea, consistent with our proxy evidence (Figures 3b-3e). The EAWM over the South China Sea is also consistent with a previous simulation of southern China based on the Community Climate System Model version 3 (CCSM3; Wen et al., 2016; Figure 3e). Here both our modeling simulation and proxy evidence suggest opposite Holocene EAWM trends over the northern East Asian marginal sea and the South China Sea.

\section{Discussion}

To examine periodicities and further assess the intrinsic mechanism of EAWM change in the frequency domain, cross-spectral analysis was conducted on clay mineral record in the northern East China Sea in this study, south-north SST gradient in the South China Sea (Huang, 2015) and loess grain size (Sun et al., 2006) with tropical Pacific ENSO proxy (Jia et al., 2018) and North American ice volumes (Bintanja et al., 2005), respectively.

Both the clay mineral and South China Sea SST records suggest a similar cycle of $50 \mathrm{ka}$ along with the ENSO-like record, with a strong coherency power at the 50-ka band for the SST record and a relatively weaker power for the clay record (Figure S6). However, no similar cycles were found with statistical robustness between the loess grain size record and ENSO proxy (Figure S7a). It has been suggested that ENSO exhibits a precession periodicity of $23 \mathrm{ka}$ during the Quaternary (Clement et al., 1999). A nonlinear mechanism with precession as the primary forcing (i.e., bundling of precession cycles) can probably explain the observed spectral features of $50 \mathrm{ka}$ in ENSO (Liu et al., 2008). In addition, modeling studies have demonstrated that ENSO can oscillate at any rational numbers (subharmonics and 


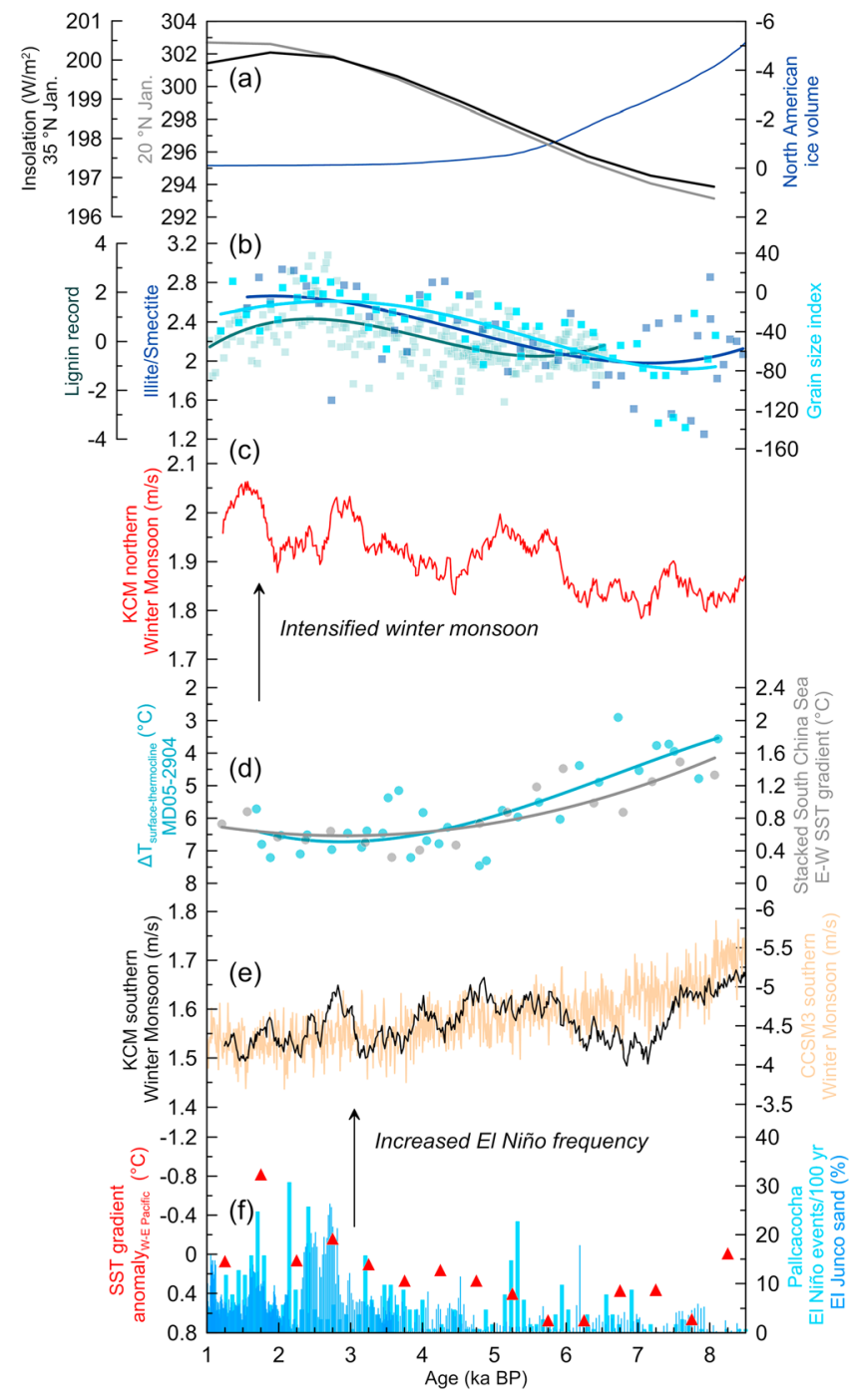

Figure 3. Comparison of proxy records of EAWM from northern East Asian marginal sea and South China Sea with global paleoenvironmental records during the last $8.5 \mathrm{ka}$. (a) Northern Hemisphere insolation at $20^{\circ} \mathrm{N}$ and 35 ${ }^{\circ} \mathrm{N}$ in January and North American ice volume; (b) EAWM proxies in northern East Asian marginal sea including clay mineral ratio, grain size index in the middle Okinawa Trough (Zheng et al., 2014), and lignin record (Hao et al., 2017) in the central Yellow Sea; (c) simulated EAWM speed in northern East Asian marginal sea with KCM; (d) EAWM proxies in South China Sea including SST gradient between west and east (Huang et al., 2011) and between surface and thermocline waters (Steinke et al., 2011); (e) simulated EAWM speed in South China Sea with KCM and EAWM wind index in southern China $\left(20-30^{\circ} \mathrm{N}, 110-130^{\circ} \mathrm{E}\right)$ simulated by CCSM3 (Wen et al., 2016); (f) zonal SST gradient between the west and east Pacific (Koutavas \& Joanides, 2012) and El Niño variability from lakes Pallcacocha, Ecuador (Moy et al., 2002), and El Junco, Galapagos (Conroy et al., 2008). Thick lines are polynomial fits shown to highlight general long-term trends from the original data sets. EAWM = East Asian winter monsoon; $\mathrm{KCM}=$ Kiel Climate Model; SST $=$ sea surface temperature . fractional subharmonics) of the annual cycle, created by nonlinear resonances with the annual cycle (Tziperman et al., 1994). Therefore, nonlinearities in the ENSO climate may be responsible for the periodicity of $50 \mathrm{ka}$ in the late Quaternary. The coherence between the EAWM records with the ENSO proxy suggests that ENSO has a strong influence on EAWM evolution in the northern East Asian marginal sea and the South China Sea. The absence of the 50-ka cycle in the loess record indicates that the EAWM over the Loess Plateau region is beyond the control of ENSO processes.

Loess grain-sized record suggests the same cycles and strong coherency power at orbital bands with North American ice volume, whereas the clay record shows a similar cycle $(23 \mathrm{ka})$ but a weak coherence with the ice volume (Figures S7b and S7d). Such coherences indicate that the North Hemisphere ice volume strongly regulated EAWM on the Loess Plateau (Hao et al., 2012) but was relatively weaker in the northern East Asian marginal sea and thus induced weak glacial-interglacial cycles in the EAWM evolution in this area. Besides, similar cycle has not been found between the South China Sea SST record and North American ice volume (Figure S7c), probably suggesting the weak influence of northern highlatitude climate change on South China Sea EAWM (Huang, 2015).

Long-term variations in the EAWM over the northern East Asian marginal sea, as recorded in the illite/smectite ratio in the IODP Site U1429 sediments, display strong anticorrelations with the EAWM over the South China Sea. Variations in the single factor of insolation or Northern Hemisphere ice volume cannot explain the distinct evolution of EAWM in these two regions (Figures $2 \mathrm{a}-2 \mathrm{~b}$ and $3 \mathrm{a}-3 \mathrm{~b}$ ). However, both the EAWM in the northern East Asian marginal sea and the South China Sea coevolve with zonal SST gradients (de Garidel-Thoron et al., 2005) and zonal SST gradient anomalies (Jia et al., 2018) in the tropical Pacific (Figures 2d-2f). These equatorial Pacific SST gradients and gradient anomalies exhibit an overall decreasing trend from $~ 300$ to $160 \mathrm{ka}$. This suggests that the tropical Pacific was dominated by a transition from $\mathrm{La}$ Niña-like to El Niño-like conditions during this period (de GaridelThoron et al., 2005; Jia et al., 2018). This ENSO-like evolution is associated with the reinforcement of the EAWM in the northern region of the East Asian marginal sea and a weakened EAWM in the South China Sea. After $\sim 160 \mathrm{ka}$, increases in the zonal SST gradient records and gradient anomalies imply the relative intensification resembling La Niña-like conditions. This time interval is also associated with a gradually weakened EAWM in the study region, and a strengthened EAWM in the South China Sea. On multimillennial scales during the Holocene, such connections between the EAWM in the northern East Asian marginal sea and South China Sea and the ENSO-like record (Conroy et al., 2008; Koutavas \& Joanides, 2012; Moy et al., 2002) can also be observed (Figure 3b-f).

A model for the response of the global atmosphere to the monthly varying tropical Pacific SST gradient during 1948-1999 with CCSM3 argued that a mature phase of El Niño in winter would lead to a strengthened EAWM over the north of East Asia but a weakened one over the south (Sun \&
phase, anomalously negative geopotential height centered over the northYang, 2005). During the El Niño phase, anomalously negative geopotential height centered over the northeastern part of East Asia and the surrounding sea, including Northeast China, the Korean Peninsula, the northern region of the East Asian marginal sea, and part of the Japan Sea (East Sea). In contrast, an anomalously positive geopotential height center occurred over southern East Asia (Figure S8a). Meanwhile, 

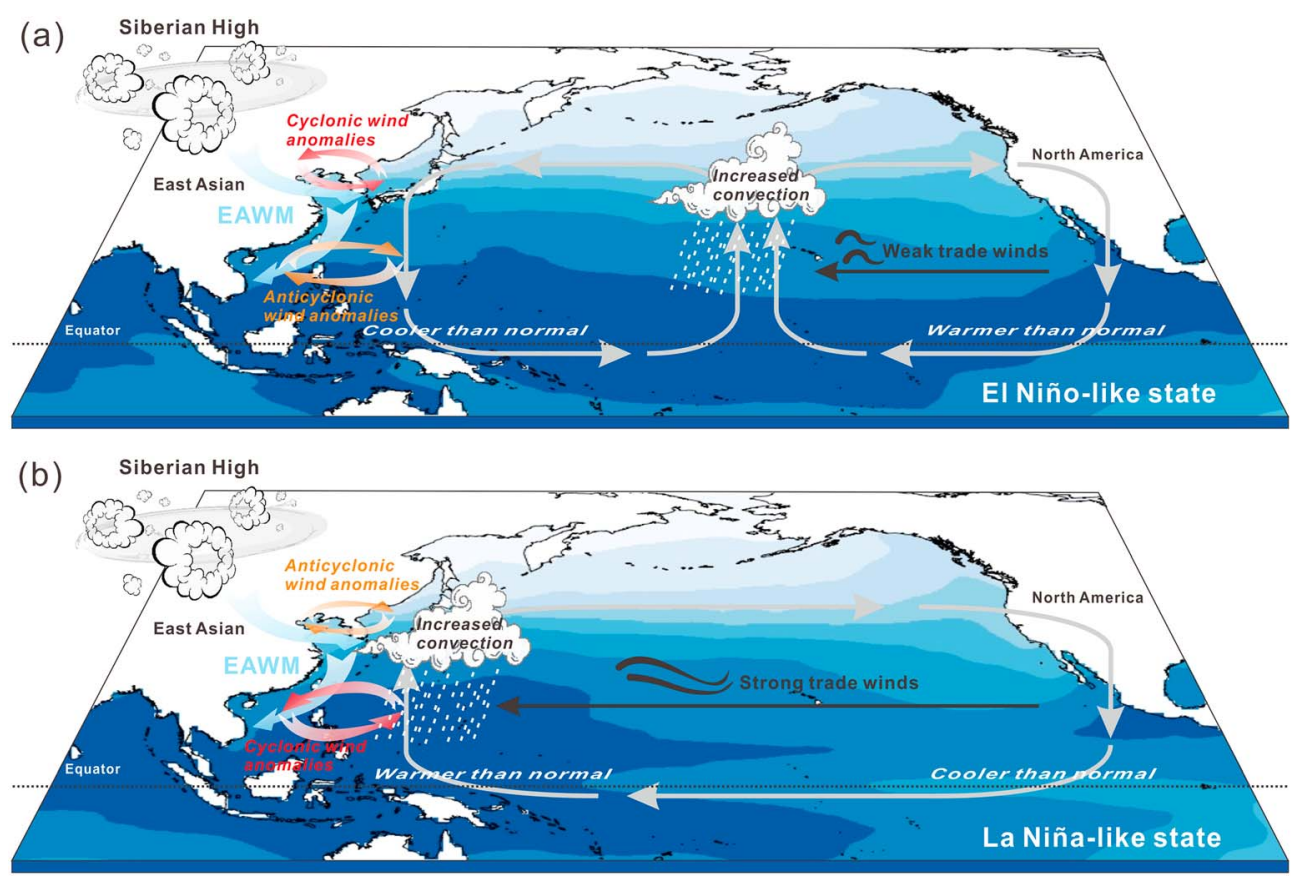

Figure 4. El Niño-Southern Oscillation forcing on the spatially variable evolution of the East Asian winter monsoon during the late Quaternary. (a) El Niño-like state; (b) La Niña-like state. Global SST data of El Niño-like and La Niña-like states are plotted based on a typical El Niño-Southern Oscillation process in November 1997 and November 1998, respectively. The SST data are from COBE-SST2 data provided by the NOAA/OAR/ESRL PSD, Boulder, Colorado, USA, from their website (https://www.esrl.noaa.gov/psd/).

anomalous cyclones and anticyclones developed over the northeastern part of East Asia and the western Pacific, respectively (Figure S8b). Such cyclones can lead to the occurrence of anomalous northwesterlies over the northern East Asian marginal sea and, consequently, a strengthened EAWM in this region. In contrast, the anticyclone over the southern East Asia results in anomalous southwesterlies over the South China Sea and, thus, a weakened EAWM in this area (Figure S8b). In addition, the comparison of the Niño 3.4 index (December-February) and observed winter wind speeds (December-February) in the northern East Asian marginal sea (the Yellow Sea) and South China Sea from 1982 to 2016 also suggests antiphased winter wind speeds in these two regions on the decadal scale (Figure S9). More importantly, both of them show good coherence with the Niño 3.4 index, suggesting that the El Niño conditions correspond to the decreased winter wind speeds in the South China Sea but the increased winter wind speeds in the Yellow Sea. The opposite situation occurred under the La Niña conditions (Figure S9). Therefore, based on the spectral analysis and evolutionary trend comparison, we invoke a similar mechanism with the modern simulation and observation results to explain the observed antiphasing of EAWM evolution between the northern East Asian marginal sea and the South China Sea during the last $300 \mathrm{ka}$ and through the Holocene. During the El Niño-like intervals, the anomalous northwesterlies in the northern East Asian marginal sea led to the strengthened EAWM prevailing in this region (Figure 4a). In contrast, anomalous southwesterlies in the South China Sea favored the occurrence of a weakened EAWM (Figure 4a). The opposite situation occurred under La Niña-like conditions (Figure 4b).

The comparison between EAWM records obtained at IODP Site U1429 and SST gradients in the South China Sea, together with the simulated results reveals, for the first time, a strong north-south spatial discrepancy in the EAWM evolution in East Asian marginal sea. The results of this study support the teleconnection between East Asia and ENSO-like processes during the late Quaternary. Variations in the ENSO-like climate could have significantly regulated the long-term strength of the EAWM in the northern East Asian marginal sea and South China Sea. In the context of global warming, an increased frequency of extreme El Niño and La Niña events (Cai et al., 2014; Cai et al., 2015) will very likely enlarge the spatial discrepancies in EAWM intensities and lead to higher frequencies of extremely cold/warm winters in this region. Our findings 
highlight the role of tropical forcing in East Asian climate change through ocean-atmosphere interactions and have important implications for future projections of winter climate in this densely populated region.

\section{Conclusions}

Based on the sediment input from the East Asian continent to the northern East Asian marginal sea, we reconstruct the history of the EAWM over the northern East Asian marginal sea since the last $300 \mathrm{ka}$. The long-term evolution of the EAWM in this region intensified from $~ 300$ to $160 \mathrm{ka}$ and then gradually weakened from $\sim 160 \mathrm{ka}$ to the present, displaying strong anticorrelations with the EAWM over the South China Sea. Both our EAWM proxy and KCM simulated results suggest opposite Holocene EAWM trends over the northern East Asian marginal sea and the South China Sea.

We attribute this spatial discrepancy in EAWM evolution to an ENSO-like control, which generates cyclonic/anticyclonic wind anomalies in the northern/southern East Asian marginal sea. The development of dominant El Niño-like conditions corresponds to a strengthened winter monsoon over the northern East Asian marginal sea and a weakened winter monsoon over the South China Sea. In contrast, the development of dominant La Niña-like conditions is associated with a weakened winter monsoon over the northern East Asian marginal sea and an intensified winter monsoon over the South China Sea.

\section{Acknowledgments}

We acknowledge the Integrated Ocean Drilling Program and the scientific party and technicians of IODP Expedition 346 for recovering the samples. We are grateful to Vyacheslav Khon in Kiel University for helping in numerical experiments and improvement of the manuscript and Xuguang Sun in Nanjing University for providing their results of modern CCSM3 simulation. We thank the two anonymous reviewers for their constructive comments. This work was supported by the National Natural Science Foundation of China (41622603, 41576034, 41806055, U1606401), National Program on Global Change and Air-Sea Interaction (GASI-GEOGE-03), China Postdoctoral Science Foundation Funded Project (2018M632730), Taishan and Aoshan Talents program (2017ASTCP-ES01), and Innovation project of Qingdao National Laboratory for Marine Science and Technology (2016ASKJ13 and MGQNLM-TD201805). All data necessary to assess the validity of this research are archived at NOAA's National Centers for Environmental Information.

\section{References}

Beny, F., Toucanne, S., Skonieczny, C., Bayon, G., \& Ziegler, M. (2018). Geochemical provenance of sediments from the northern East China Sea document a gradual migration of the Asian Monsoon belt over the past 400,000 years. Quaternary Science Reviews, 190, 161-175. https://doi.org/10.1016/j.quascirev.2018.04.032

Bintanja, R., van de Wal, R. S., \& Oerlemans, J. (2005). Modelled atmospheric temperatures and global sea levels over the past million years. Nature, 437(7055), 125-128. https://doi.org/10.1038/nature03975

Cai, W., Borlace, S., Lengaigne, M., Rensch, P. V., Collins, M., Vecchi, G., et al. (2014). Increasing frequency of extreme El Niño events due to greenhouse warming. Nature Climate Change, 4(2), 111-116. https://doi.org/10.1038/nclimate2100

Cai, W., Wang, G., Santoso, A., Mcphaden, M. J., Wu, L., Jin, F. F., et al. (2015). Increased frequency of extreme La Niña events under greenhouse warming. Nature Climate Change, 5(2), 132-137. https://doi.org/10.1038/nclimate2492

Clement, A. C., Seager, R., \& Cane, M. A. (1999). Orbital controls on the El Niño/Southern Oscillation and the tropical climate. Paleoceanography \& Paleoclimatology, 14(4), 441-456. https://doi.org/10.1029/1999PA900013

Conroy, J. L., Overpeck, J. T., Cole, J. E., Shanahan, T. M., \& Steinitz-Kannan, M. (2008). Holocene changes in eastern tropical Pacific climate inferred from a Galápagos lake sediment record. Quaternary Science Reviews, 27(11-12), 1166-1180. https://doi.org/10.1016/j. quascirev.2008.02.015

de Garidel-Thoron, T., Rosenthal, Y., Bassinot, F., \& Beaufort, L. (2005). Stable sea surface temperatures in the western Pacific warm pool over the past 1.75 million years. Nature, 433(7023), 294-298. https://doi.org/10.1038/nature03189

Diekmann, B., Hofmann, J., Henrich, R., Fütterer, D. K., Röhl, U., \& Wei, K.-Y. (2008). Detrital sediment supply in the southern Okinawa Trough and its relation to sea-level and Kuroshio dynamics during the late Quaternary. Marine Geology, 255(1-2), 83-95. https://doi.org/ 10.1016/j.margeo.2008.08.001

Fan, D., Yang, Z., Mao, D., \& Guo, Z. (2001). Clay minerals and geochemistry of the sediments from the Yangtze and Yellow Rivers. Marine Geology \& Quaternary Geology, 21(4), 7-12. https://doi.org/10.16562/j.cnki.0256-1492.2001.04.002

Gao, H., Chen, L., Jia, X., Ke, Z., Han, R., Zhang, P., et al. (2008). Analysis of the severe cold surge, ice-snow and frozen disasters in South China during January 2008: II. Possible climatic causes. Meteorological Monthly, 34, 101-106. https://doi.org/10.7519/j.issn.10000526.2008.4.013

Grant, K. M., Rohling, E. J., Ramsey, C. B., Cheng, H., Edwards, R. L., Florindo, F., et al. (2014). Sea-level variability over five glacial cycles. Nature Communications, 5(1). https://doi.org/10.1038/ncomms6076

Hao, Q., Wang, L., Oldfield, F., Peng, S., Qin, L., Song, Y., et al. (2012). Delayed build-up of Arctic ice sheets during 400,000-year minima in insolation variability. Nature, 490(7420), 393-396. https://doi.org/10.1038/nature11493

Hao, T., Liu, X., Ogg, J., Liang, Z., Xiang, R., Zhang, X., et al. (2017). Intensified episodes of East Asian Winter Monsoon during the middle through late Holocene driven by North Atlantic cooling events: High-resolution lignin records from the South Yellow Sea, China. Earth and Planetary Science Letters, 479, 144-155. https://doi.org/10.1016/j.epsl.2017.09.031

Howell, P., Pisias, N., Balance, J., Baughman, J., \& Ochs, L. (2006). ARAND time-series analysis software. Brown University, Providence RI.

Huang, E. (2015). A comparison of the East Asian winter monsoon reconstructions from terrestrial and marine sedimentary records since the Mid-Pleistocene. Quaternary Science, 35(6), 1331-1341. https://doi.org/10.11928/j.issn.1001-7410.2015.06.03

Huang, E., Tian, J., \& Steinke, S. (2011). Millennial-scale dynamics of the winter cold tongue in the southern South China Sea over the past $26 \mathrm{ka}$ and the East Asian winter monsoon. Quaternary Research, 75(1), 196-204. https://doi.org/10.1016/j.yqres.2010.08.014

Jia, Q., Li, T., Xiong, Z., Steinke, S., Jiang, F., Chang, F., \& Qin, B. (2018). Hydrological variability in the western tropical Pacific over the past $700 \mathrm{kyr}$ and its linkage to Northern Hemisphere climatic change. Palaeogeography Palaeoclimatology Palaeoecology, $493,44-54$. https://doi.org/10.1016/j.palaeo.2017.12.039

Khon, V., Schneider, B., Latif, M., Park, W., \& Wengel, C. (2018). Evolution of Eastern Equatorial Pacific Seasonal and Interannual Variability in response to orbital forcing during the Holocene and Eemian from Model Simulations. Geophysical Research Letters, 45, 9843-9851. https://doi.org/10.1029/2018GL079337

Kim, D. C. (1979). Recent clay minerals of the Yeongsan estuary and the adjacent continental shelf. Department of Oceanography, the Graduate School, Seoul National University.

Koutavas, A., \& Joanides, S. (2012). El Niño-Southern Oscillation extrema in the Holocene and Last Glacial Maximum. Paleoceanography, 27, PA4208. https://doi.org/10.1029/2012PA002378 
Kutzbach, J. E. (1981). Monsoon climate of the early Holocene: Climate experiment with the Earth's orbital parameters for 9000 years ago. Science, 214(4516), 59-61. https://doi.org/10.1126/science.214.4516.59

Li, C., Shi, X., Kao, S., Chen, M., Liu, Y., Fang, X., et al. (2012). Clay mineral composition and their sources for the fluvial sediments of Taiwanese rivers. Chinese Science Bulletin, 57(6), 673-681. https://doi.org/10.1007/s11434-011-4824-1

Li, D., Zhao, M., \& Tian, J. (2017). Low-high latitude interaction forcing on the evolution of the 400 kyr cycle in East Asian winter monsoon records during the last 2.8 Myr. Quaternary Science Reviews, 172, 72-82. https://doi.org/10.1016/j.quascirev.2017.08.005

Li, L., Chen, Y., Wang, H., \& Juan, H. (2012). Sea surface temperature change in South China sea since Pleistocene and its paleoclimatic implications. Marine Geology \& Quaternary Geology, 32(4), 1-8. https://doi.org/10.3724/SP.J.1140.2012.04001

Li, Y., Song, Y., Zeng, M., Lin, W., Orozbaev, R., Cheng, L., et al. (2018). Evaluating the paleoclimatic significance of clay mineral records from a late Pleistocene loess-paleosol section of the Ili Basin, Central Asia. Quaternary Research, 89(3), 660-673. https://doi.org/10.1017/ qua. 2017.58

Licht, A., Pullen, A., Kapp, P., Abell, J., \& Giesler, N. (2016). Eolian cannibalism: Reworked loess and fluvial sediment as the main sources of the Chinese loess plateau. Geological Society of America Bulletin, 128(5-6), 944-956. https://doi.org/10.1130/B31375.1

Liu, T., \& Ding, Z. (1998). Chinese loess and the paleomonsoon. Annual Review of Earth and Planetary Sciences, 26(1), 111-145. https://doi. org/10.1146/annurev.earth.26.1.111

Liu, Z., Cleaveland, L. C., \& Herbert, T. D. (2008). Early onset and origin of 100-kyr cycles in Pleistocene tropical SST records. Earth and Planetary Science Letters, 265(3-4), 703-715. https://doi.org/10.1016/j.epsl.2007.11.016

Milliman, J. D., \& Farnsworth, K. L. (2013). River discharge to the coastal ocean: A global synthesis. Cambridge: Cambridge University Press. https://doi.org/10.1017/CBO9780511781247

Moy, C. M., Seltzer, G. O., Rodbell, D. T., \& Anderson, D. M. (2002). Variability of El Niño/Southern Oscillation activity at millennial timescales during the Holocene epoch. Nature, 420(6912), 162-165. https://doi.org/10.1038/nature01194

Ohtsubo, M., Egashira, K., \& Kashima, K. (1995). Depositional and post-depositional geochemistry, and its correlation with the geotechnical properties of marine clays in Ariake Bay, Japan. Géotechnique, 45(3), 509-523. https://doi.org/10.1680/geot.1995.45.3.509

Pang, C., Li, K., \& Hu, D. (2016). Net accumulation of suspended sediment and its seasonal variability dominated by shelf circulation in the Yellow and East China Seas. Marine Geology, 371, 33-43. https://doi.org/10.1016/j.margeo.2015.10.017

Pang, C. G., Yang, Y., \& Liu, Z. L. (2010). Transportation pattern of suspended sediment and its forming mechanism in the Yellow and East China Sea. Journal of Sedimentary Research, 3, 24-30. https://dx.doi.org/10.16239/j.cnki.0468-155x.2010.03.003

Park, W., Keenlyside, N., Latif, M., Ströh, A., Redler, R., Roeckner, E., \& Madec, G. (2009). Tropical pacific climate and its response to global warming in the Kiel climate model. Journal of Climate, 22(1), 71-92. https://doi.org/10.1175/2008JCLI2261.1

Park, Y., \& Khim, B. (1990). Clay minerals of the recent fine-grained sediments on the Korean continental shelves. Continental Shelf Research, 10(12), 1179-1191. https://doi.org/10.1016/0278-4343(90)90015-E

Rea, D. K., \& Janecek, T. R. (1981). Mass-accumulation rates of the non-authigenic inorganic crystalline (eolian) component of deep-sea sediments from the Western Mid-Pacific Mountains. In J. Thiede, T. L. Vallier, et al. (Eds.), Deep Sea Drilling Project Site 463. Initial Reports of the Deep Sea Drilling Project (Vol. 62, pp. 653-659). Washington, DC: U.S. Govt. Printing Office. https://doi.org/10.2973/dsdp. proc.62.125.1981

Ren, M., \& Shi, Y. (1986). Sediment discharge of the Yellow River (China) and its effect on the sedimentation of the Bohai and the Yellow Sea. Scientia Geographica Sinica, 6(6), 785-810. https://doi.org/10.1016/0278-4343(86)90037-3

Sagawa, T., Nagahashi, Y., Satoguchi, Y., Holbourn, A., Itaki, T., Gallagher, S. J., et al. (2018). Integrated tephrostratigraphy and stable isotope stratigraphy in the Japan Sea and East China Sea using IODP Sites U1426, U1427, and U1429, Expedition 346 Asian Monsoon. Progress in Earth and Planetary Science, 5(1), 18. https://doi.org/10.1186/s40645-018-0168-7

Schneider, B., Leduc, G., \& Park, W. (2010). Disentangling seasonal signals in Holocene climate trends by satellite-model-proxy integration. Paleoceanography, 25, PA4217. https://doi.org/10.1029/2009PA001893

Song, Z., Latif, M., Park, W., Krebs-Kanzow, U., \& Schneider, B. (2016). Influence of seaway changes during the Pliocene on tropical Pacific climate in the Kiel climate model: Mean state, annual cycle, ENSO, and their interactions. Climate Dynamics, 48(11-12), 3725-3740. https://doi.org/10.1007/s00382-016-3298-X

Steinke, S., Glatz, C., Mohtadi, M., Groeneveld, J., Li, Q., \& Jian, Z. (2011). Past dynamics of the East Asian monsoon: No inverse behaviour between the summer and winter monsoon during the Holocene. Global and Planetary Change, 78(3-4), 170-177. https://doi.org/ 10.1016/j.gloplacha.2011.06.006

Sun, X., \& Yang, X. (2005). Numerical modeling of interannual anomalous atmospheric circulation patterns over East Asia during different stages of an El Nino event. Chinese Journal of Geophysics, 48(3), 501-510. https://doi.org/10.3321/j.issn:0001-5733.2005.03.006

Sun, Y., Clemens, S. C., An, Z., \& Yu, Z. (2006). Astronomical timescale and palaeoclimatic implication of stacked 3.6-Myr monsoon records from the Chinese Loess Plateau. Quaternary Science Reviews, 25(1-2), 33-48. https://doi.org/10.1016/j.quascirev.2005.07.005

Sun, Y., Clemens, S. C., Morrill, C., Lin, X., Wang, X., \& An, Z. (2011). Influence of Atlantic meridional overturning circulation on the East Asian winter monsoon. Nature Geoscience, 5(1), 46-49. https://doi.org/10.1038/ngeo1326

Sun, Y., Kutzbach, J., An, Z., Clemens, S. C., Liu, Z., Liu, W., et al. (2015). Astronomical and glacial forcing of East Asian summer monsoon variability. Quaternary Science Reviews, 115, 132-142. https://doi.org/10.1016/j.quascirev.2015.03.009

Tada, R., Murray, R. W., Zarikian, C. A. A., Lofi, J., Anderson, W. T. Jr., Bassetti, M. A., et al. (2014). Asian Monsoon: Onset and evolution of millennial-scale variability of Asian monsoon and its possible relation with Himalaya and Tibetan Plateau uplift. In R. Tada \& R. W. Murray (Eds.), Integrated Ocean Drilling Program Preliminary Reports (Vol. 346, pp. 1-111). College Station, TX: Integrated Ocean Drilling Program https://doi.org/10.2204/iodp.proc.346.2015

Tian, J., Huang, E., \& Pak, D. K. (2010). East Asian winter monsoon variability over the last glacial cycle: Insights from a latitudinal seasurface temperature gradient across the South China Sea. Palaeogeography Palaeoclimatology Palaeoecology, 292(1-2), 319-324. https:// doi.org/10.1016/j.palaeo.2010.04.005

Tziperman, E., Stone, L., Cane, M. A., \& Jarosh, H. (1994). El Niño chaos: Overlapping of resonances between the seasonal cycle and the Pacific Ocean-atmosphere oscillator. Science, 264(5155), 72-74. https://doi.org/10.1126/science.264.5155.72

Wan, S., Li, A., Clift, P. D., \& Stuut, J.-B. W. (2007). Development of the East Asian monsoon: Mineralogical and sedimentologic records in the northern South China Sea since 20 Ma. Palaeogeography, Palaeoclimatology, Palaeoecology, 254(3-4), 561-582. https://doi.org/ 10.1016/j.palaeo.2007.07.009

Wan, S., Yu, Z., Clift, P. D., Sun, H., Li, A., \& Li, T. (2012). History of Asian eolian input to the West Philippine Sea over the last one million years. Palaeogeography Palaeoclimatology Palaeoecology, 326-328(2), 152-159. https://doi.org/10.1016/j.palaeo.2012.02.015

Wang, B., Wu, R., \& Fu, X. (2000). Pacific-East Asian teleconnection: How does ENSO affect East Asian climate? Journal of Climate, 13(9), 1517-1536. https://doi.org/10.1175/1520-0442(2000)013\%3C1517:PEATHD\%3E2.0.CO;2 
Wang, H., Yu, E., \& Song, Y. (2011). An exceptionally heavy snowfall in Northeast China: Large-scale circulation anomalies and hindcast of the NCAR WRF model. Meteorology and Atmospheric Physics, 113(1-2), 11-25. https://doi.org/10.1007/s00703-011-0147-7

Wen, X., Liu, Z., Wang, S., Cheng, J., \& Zhu, J. (2016). Correlation and anti-correlation of the East Asian summer and winter monsoons during the last 21,000 years. Nature Communications, 7(1), 11999. https://doi.org/10.1038/ncomms11999

Yamamoto, M., Sai, H., Chen, M. T., \& Zhao, M. (2013). The East Asian winter monsoon variability in response to precession during the past 150000 yr. Climate of the Past, 9(6), 2777-2788. https://doi.org/10.5194/cp-9-2777-2013

Yang, S., Jung, H. S., Lim, D. I., \& Li, C. (2003). A review on the provenance discrimination of sediments in the Yellow Sea. Earth Science Reviews, 63(1), 93-120. https://doi.org/10.1016/S0012-8252(03)00033-3

Yuan, D., Zhu, J., Li, C., \& Hu, D. (2008). Cross-shelf circulation in the Yellow and East China Seas indicated by MODIS satellite observations. Journal of Marine Systems, 70(1-2), 134-149. https://doi.org/10.1016/j.jmarsys.2007.04.002

Zhao, D., Wan, S., Toucanne, S., Clift, P. D., Tada, R., Révillon, S., et al. (2017). Distinct control mechanism of fine-grained sediments from Yellow River and Kyushu supply in the northern Okinawa Trough since the last glacial. Geochemistry, Geophysics, Geosystems, 18, 2949-2969. https://doi.org/10.1002/2016GC006764

Zheng, X., Li, A., Kao, S., Gong, X., Frank, M., Kuhn, G., et al. (2016). Synchronicity of Kuroshio Current and climate system variability since the Last Glacial Maximum. Earth and Planetary Science Letters, 452, 247-257. https://doi.org/10.1016/j.epsl.2016.07.028

Zheng, X., Li, A., Wan, S., Jiang, F., Kao, S. J., \& Johnson, C. (2014). ITCZ and ENSO pacing on East Asian winter monsoon variation during the Holocene: Sedimentological evidence from the Okinawa Trough. Journal of Geophysical Research: Oceans, 119, 4410-4429. https://doi.org/10.1002/2013JC009603 